\title{
Evaluation of bio-oil compounds of catalytic fast pyrolysis by multivariate analysis
}

\section{Çokdeğişkenli analiz ile katalitik hızlı pirolizin biyoyağ bileşenlerinin değerlendirilmesi}

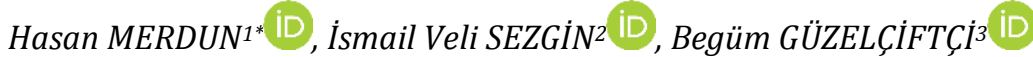 \\ ${ }^{1}$ Department of Environmental Engineering, Faculty of Engineering, Akdeniz University, 07058 Antalya, Turkey. \\ merdun@alumni.clemson.edu \\ ${ }^{2}$ Department of Environmental Engineering, Faculty of Engineering, Akdeniz University, 07058 Antalya, Turkey. \\ ivsezgin@gmail.com \\ ${ }^{3}$ Energy Environment System Engineering Department, Faculty of Engineering, University of Seoul, Seoul, Korea. \\ begumgc@hotmail.com
}

\section{Abstract}

The presence and amounts of chemicals in bio-oil produced by catalytic fast pyrolysis are affected by the process parameters, hence, the relationships between the chemicals and process parameters need to be investigated in detail by multivariate analysis techniques. The present work classifies the most available 11 chemicals in bio-oil based on the 24 samples (treatments) of catalytic fast pyrolysis experiments of municipal solid wastes by using principle components analysis (PCA) and hierarchical cluster analysis (HCA). There were 3 principle components (PCs), but the first 2 PCs explained $74 \%$ of the total variance. The samples and variables (chemicals) were clustered into 4 and 2 different groups, respectively, in PCA. The samples and variables were clustered in 2 main groups and a few subgroups in HCA. Both PCA and HCA results showed that there was a clear grouping in the samples and variables.

Keywords: Biomass, Fast pyrolysis, Catalyst, Principal components analysis, Hierarchical cluster analysis

\section{Introduction}

The concerns related to the availability, distribution, and environmental issues of fossil fuels [1] motivate researchers to conduct studies on bioenergy, a renewable energy produced from biomass resources, in all over the world. Biomass, all organic or biological materials originated from plants or animals, is mainly composed of cellulose, hemicelluloses, lignin, extractives (lipids, proteins, simple sugars, starches, and water), and ash [2]. Bulky and solid raw biomass with relatively low energy density can be converted to more usable liquid or gaseous biofuels [3].

Pyrolysis, a thermochemical conversion technology, is the conversion of biomass into solid (biochar), liquid (bio-oil), and gaseous products at around $500^{\circ} \mathrm{C}$ in the absence of oxygen and atmospheric condition [4]. The distribution of the pyrolysis products depends on the process parameters such as pyrolysis temperature, heating rate, residence time, reactor type, catalyst type and amount, and carrier gas flow rate [5]. Fast pyrolysis is a type of pyrolysis in which the main product is bio-oil up to $75 \%$ under the specific process conditions such as fine biomass particle size $(<1 \mathrm{~mm})$; a carefully controlled temperature $\left(\sim 500{ }^{\circ} \mathrm{C}\right)$, high heating rate $\left(>200{ }^{\circ} \mathrm{C} \mathrm{s}^{-1}\right)$, short hot vapor residence time $(<2 \mathrm{~s})$, and rapid cooling of the vapors [3].
Öz

Katalitik hizlı piroliz yöntemi ile üretilen biyoyağdaki kimyasalların varlığı ve verimleri proses parametreleri tarafindan etkilenmekte, dolayısıyla, kimyasallar ve proses parametreleri arasındaki ilișkiler çokdeğişkenli analiz teknikleri ile detaylı bir șekilde araștırılmalıdır. Bu çalıșma temel bileșenler analizi (PCA) ve hiyerarașik sınıflama analizini (HCA) kullanarak belediye katı atıklarının katalitik hızlı piroliz deneylerinin 24 örneğine (konusuna) bağlı olarak biyoyağ içerisinde en fazla bulunan 11 kimyasal maddeyi sinıflandirmaktadır. Üc temel bileșen olușmuș, fakat bunların ilk ikisi toplam değișkenliğin \%74'ünü açıklamıștır. PCA'inde örnekler ve değiskenler (kimyasallar) sırasılyla 4 ve 2 farklı grupta toplanmıștır. HCA'inde ise örnekler ve değişkenler 2 ana grup ve birkaç alt grupta toplanmıștır. PCA ve HCA'nin her ikisinin sonuçları da örneklerde ve değișkenlerde açık bir gruplanmanın olduğunu göstermiştir.

Anahtar kelimeler: Biyokütle, Hızlı piroliz, katalizör, Temel bileşenler analizi, Hiyerarșik sınıflama analizi

Bio-oil may contain over 300 chemicals mainly of acids, aldehydes, alcohols, sugars, esters, ketones, and aromatics [6] Catalytic fast pyrolysis is applied to improve the quality of biooil and therefore affects the distribution of chemicals in bio-oil [7],[8]. Bio-oil can be used as combustion fuels for electricity and heat production in boilers, furnaces, and combustors [9],[10], diesel engines [11] and gas turbines [12]. In addition, bio-oil can be used as a feedstock for production of chemicals, such as phenols for resin production, additives in fertilizing and pharmaceutical industries, flavoring agents in food industries and other special chemicals [13],[14].

Principal component analysis (PCA) and hierarchical cluster analysis (HCA) are the two most common multivariate statistical methods used in multivariable data analyses [15]. PCA is commonly used to reduce data [16] and to extract a small number of latent factors (principal components-PCs) for analyzing relationships among samples or variables. HCA helps someone to gather objects into groups based on their characteristics, where elements in the same group are similar to each other while elements in different groups are heterogeneous. Multivariate analysis techniques, PCA and/or HCA, have been utilized in different biomass energy or bioenergy studies to evaluate their potentials. The effects of different factors on the chemical composition of switchgrass 
and the generation of biofuels [17], the effects of various catalysts on the distribution of pyrolysis products [18], the effects of different growing places and species of the biomass on the distribution of pyrolysis products [19] and the effects of pyrolysis temperature on the distribution of pyrolysis products derived from different biomass materials [20]. In general, the application of PCA and/or HCA to assess the bioenergy potential of different biomasses is limited and, more importantly, the effects of catalyst properties (amount and particle size) on the distribution of pyrolysis products have not been studied.

Therefore, the objective of this study was to assess the distribution of chemicals in bio-oil based on the pyrolysis experimental conditions or treatments. Firstly, bio-oil samples were obtained by catalytic fast pyrolysis experiments of municipal solid wastes (MSW). Then, bio-oil samples were analyzed in gas chromatography-mass spectroscopy (GC-MS) to determine the distributions of chemicals. Finally, these chemicals were classified based on the samples/treatments by using chemometric approaches on the basis of PCA and HCA.

\section{Materials and methods}

\subsection{Catalytic fast pyrolysis experiments}

The most common organic materials present in municipal solid wastes (MSW) in Antalya Province of Turkey were papercardboard, yard wastes, and food wastes. Yard wastes were airdried for two weeks. Food wastes were cut smaller pieces by a mixer. After food wastes were dried in an oven for 24 hours under $105{ }^{\circ} \mathrm{C}$ temperature to lower the moisture level around $30 \%$, they were further air-dried for two weeks. The dried yard and food wastes were milled and sieved to get the desired biomass particle size $(0.5-1.0,1.0-1.5$, and 1.5-2.0 mm). Biomass samples were kept in a $1 \mathrm{~L}$ air-proof glass cups for experiments.

Catalyst is generally used to improve/upgrade bio-oil which has unwanted properties such as high oxygen content, low calorific value, high viscosity, and instability. Natural catalyst, dolomite, was used in this study to improve bio-oil quality. Before using in experiments catalyst samples were calcinated in a vacuumed oven for $2 \mathrm{hrs}$ at $60^{\circ} \mathrm{C}, 1 \mathrm{~h}$ at $80^{\circ} \mathrm{C}, 1 \mathrm{~h}$ at $120^{\circ} \mathrm{C}$, and 2 hrs at $5500^{\circ} \mathrm{C}$.

Fast pyrolysis experiments were conducted in a specially designed laboratory scale drop-tube reactor experimental system (Figure 1). Biomass sample (a mixture of yard wastes and food wastes ( $7.5 \mathrm{~g}$ each)) was first placed into biomass bed, then the reactor temperature was set to the desired value, finally biomass sample was dropped into the reactor.

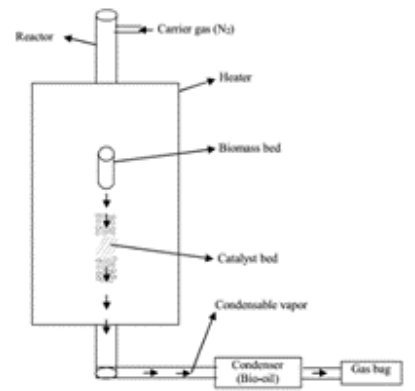

(a)

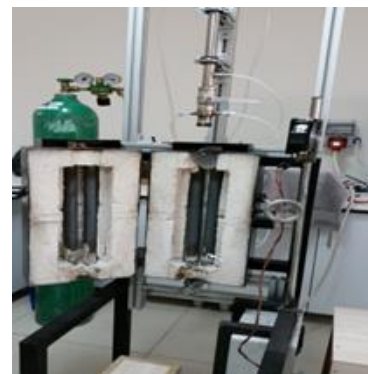

(b)
Figure 1(a): 2D view of fast pyrolysis experimental system and (b): Picture of fast pyrolysis experimental system.
Pyrolysis vapor passing through the catalyst bed was condensed in a condenser as bio-oil, but non-condensable gases were collected in a gas bag. In fast pyrolysis experiments, the effects of carrier gas $\left(\mathrm{N}_{2}\right)$ flow rate, catalyst amount, and catalyst particle size on the yield and quality of bio-oil were investigated. Fast pyrolysis process parameters or treatments of this study is presented in Table 1. Three parameters (carrier gas flow rate and amount and particle size of catalyst) with three different levels of each parameter resulted in 27 experimental treatments as in Table 1 . A $15 \mathrm{~g}$ biomass sample, pyrolysis temperature of $500{ }^{\circ} \mathrm{C}$, and pyrolysis (reaction) time of $5 \mathrm{~min}$. were used in all fast pyrolysis experiments. The yields of bio-oil collected in condenser and biochar remained in reactor after the experiment were determined by mass balance. GC-MS analyses were made by Agilent 6890 GC and 5973 inert MS brand GC-MS system in the Scientific and Technological Research Center of İnönü University. Analyses were performed by using $2 \mu \mathrm{L}$ sample under the maximum temperature of $350{ }^{\circ} \mathrm{C}$ for 98 minutes. Capiler Agilent 19091N-136 column (60 $\mathrm{m} \times 0.25 \mathrm{~mm} \times 0.25 \mu \mathrm{m})$ was used for gas chromatography separation. After the GC furnace awaited for 10 minutes at the $60{ }^{\circ} \mathrm{C}$ initial temperature, the temperature reached $350{ }^{\circ} \mathrm{C}$ with a heating rate of $5 \circ / \mathrm{min}$. Helium was used as a carrier gas with a constant flow rate of $1.7 \mathrm{~mL} / \mathrm{min}$ in the GC analysis. The names, retention times, and relative abundance (\%area) of chemical compounds in bio-oil samples were determined by GC-MS. The results of the experiment \#5, which has the highest bio-oil yield, are tabulated in Table 2 and and the corresponding chromatogram is peresented in Figure 2.

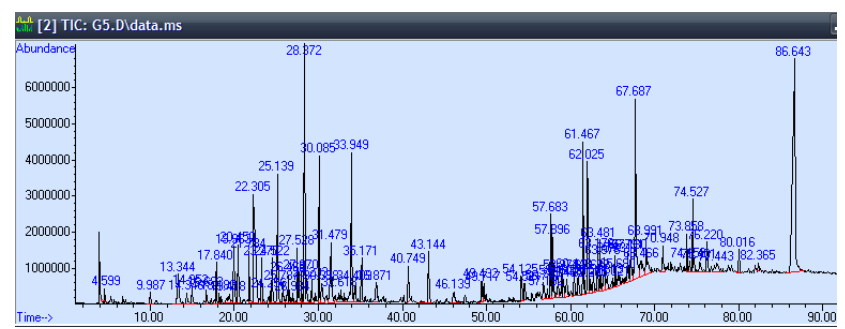

Figure 2: GC-MS chromatogram of bio-oil obtained from the experiment \#5 (peak numbers refer to tentative identification of the compounds listed in Table 2).

The chemicals with \%area $>0.80$ were used in Table 2 . However, the number of 11 chemicals in bio-oil samples with the highest amounts or \%areas were selected to use in PCA and HCA analyses. The names and codes of chemicals used in this study is illustrated in Table 3.

\subsection{Principle component analysis (PCA) and hierarchical cluster analysis (HCA)}

PCA is a powerful chemometrics technique to reduce high dimensional data sets to lower dimensions by means of PCs [21]. PCA is a method to determine the samples and variables which are close to each other. A PCA model for a given multidimensional data set can be expressed as given below.

$$
\mathrm{A}=\mathrm{T} \times \mathrm{B}+\mathrm{E}_{\mathrm{A}}
$$

Where, $\mathrm{A}$ is $\mathrm{n} \times \mathrm{m}$ matrix of original data, $\mathrm{n}$ is the number of samples, $\mathrm{m}$ is the number of variables, $\mathrm{T}$ is $\mathrm{n} \mathrm{x} \mathrm{h}$ matrix of score vectors or principal component (PC) scores, $h$ is the number of PCs that must be equal or less than the smallest of $n$ or $m, B$ is $h$ $\mathrm{x} m$ matrix of loading vectors which relates the PC scores to the original data, $\mathrm{E}_{\mathrm{A}}$ is $\mathrm{n} \mathrm{x}$ m matrix of residuals. 
Table 1: Fast pyrolysis experimental treatments.

\begin{tabular}{|c|c|c|c|}
\hline Experiment No & Carrier Gas $\left(\mathrm{N}_{2}\right)$ Flow $(\mathrm{mL} / \mathrm{min})$ & Catalyst Amount (g) & Catalyst Particle Size $(\mathrm{mm})$ \\
\hline 1 & 500 & 3.75 & $0.50-1.00$ \\
\hline 2 & 500 & 3.75 & $1.00-1.50$ \\
\hline 3 & 500 & 3.75 & $1.50-2.00$ \\
\hline 4 & 500 & 5.00 & $0.50-1.00$ \\
\hline 5 & 500 & 5.00 & $1.00-1.50$ \\
\hline 6 & 500 & 5.00 & $1.50-2.00$ \\
\hline 7 & 500 & 7.50 & $0.50-1.00$ \\
\hline 8 & 500 & 7.50 & $1.00-1.50$ \\
\hline 10 & 1000 & 3.75 & $0.50-1.00$ \\
\hline 11 & 1000 & 3.75 & $1.00-1.50$ \\
\hline 12 & 1000 & 3.75 & $1.50-2.00$ \\
\hline 13 & 1000 & 5.00 & $0.50-1.00$ \\
\hline 14 & 1000 & 5.00 & $1.00-1.50$ \\
\hline 15 & 1000 & 5.00 & $1.50-2.00$ \\
\hline 16 & 1000 & 7.50 & $0.50-1.00$ \\
\hline 17 & 1000 & 7.50 & $1.00-1.50$ \\
\hline 18 & 1000 & 7.50 & $1.50-2.00$ \\
\hline 20 & 1500 & 3.75 & $1.00-1.50$ \\
\hline 21 & 1500 & 3.75 & $1.50-2.00$ \\
\hline 22 & 1500 & 5.00 & $0.50-1.00$ \\
\hline 23 & 1500 & 5.00 & $1.00-1.50$ \\
\hline 24 & 1500 & 5.00 & $1.50-2.00$ \\
\hline 25 & 1500 & 7.50 & $0.50-1.00$ \\
\hline 26 & 1500 & 7.50 & $1.00-1.50$ \\
\hline 27 & 1500 & 7.50 & $1.50-2.00$ \\
\hline
\end{tabular}

Table 2: Main chemical compounds present in bio-oil identified by GC-MS obtained through the experiment \#5.

\begin{tabular}{|c|c|c|}
\hline \multirow[b]{2}{*}{ Name of Chemical Compound } & $\mathrm{RT}^{*}$ & RA \\
\hline & $(\min )$ & (\%Area) \\
\hline pyridine & 12.34 & 1.20 \\
\hline nitroso dimethylamine & 17.84 & 1.02 \\
\hline 2-cyclopenten-1-one & 19.96 & 2.05 \\
\hline 3-hepten-1-ol, acetate & 20.45 & 1.73 \\
\hline acetic acid & 22.30 & 7.97 \\
\hline 2-propanone, 1-(acetyloxy)- & 23.27 & 0.90 \\
\hline 2-furyl-methylketone & 24.52 & 0.92 \\
\hline propanoic acid & 25.14 & 3.90 \\
\hline 2-furancarboxaldehyde, 5-methyl- & 26.46 & 0.89 \\
\hline butanoic acid & 27.53 & 1.52 \\
\hline furfuryl alcohol & 28.38 & 3.87 \\
\hline mepivacaine metabolite & 30.09 & 2.83 \\
\hline 3-methyl-2(5h)-furanone & 30.40 & 0.87 \\
\hline $2(5 \mathrm{~h})$-furanone & 31.48 & 2.10 \\
\hline 3,4-dimethyl-1,2-cyclopentadione & 32.62 & 0.93 \\
\hline 1,2-cyclopentanedione, 3 -methyl- & 33.95 & 3.84 \\
\hline guaiacol & 35.17 & 1.06 \\
\hline 2-cyclopenten-1-one, 3-ethyl-2-hydroxy & 36.87 & 0.95 \\
\hline maltol & 40.75 & 0.99 \\
\hline phenol & 43.14 & 2.03 \\
\hline p-cresol & 49.43 & 0.81 \\
\hline 2,3-anhydro-d-mannosan & 57.68 & 2.11 \\
\hline 2,6-dimethoxyphenol & 57.90 & 1.34 \\
\hline 3-pyridinol, 2-methyl- & 58.98 & 1.04 \\
\hline $\begin{array}{l}\text { 1,4:3,6-dianhydro-.alpha.-d- } \\
\text { glucopyranose }\end{array}$ & 61.47 & 2.87 \\
\hline 4-pyridinol & 62.03 & 2.52 \\
\hline 2,5-pyrrolidinedione & 63.18 & 0.80 \\
\hline 5-hydroxymethyldihydrofuran-2-one & 63.48 & 0.94 \\
\hline 1,2-benzenediol, 3-methoxy- & 63.98 & 0.95 \\
\hline phenol, 2,6-dimethoxy- & 65.82 & 0.80 \\
\hline 1,2-benzenediol, 3-methyl- & 67.13 & 1.86 \\
\hline 1,2-benzenediol & 67.69 & 4.67 \\
\hline 5,8-dicyano-2-naphthol & 68.47 & 1.40 \\
\hline 1,2-benzenediol, 4-methyl- & 68.99 & 1.77 \\
\hline 1,4-benzenediol & 74.53 & 1.54 \\
\hline 1h-tetrazole & 76.22 & 1.25 \\
\hline levoglucosan & 86.64 & 17.23 \\
\hline
\end{tabular}

*RT: Retention time. RA: Relative Abundance.
Table 3: Chemical compounds in bio-oil and their codes.

\begin{tabular}{cc}
\hline Code for Chemicals & Chemicals in bio-oil \\
A & Acetic acid, urea, thiirane \\
B & Propanoic acid \\
C & Furfuryl alcohol \\
D & Mepivacaine metabolite \\
E & 1,2-Cyclopentanedione, 3-methyl \\
F & Phenol compounds \\
G & 2,3-Anhydro-d-mannosan \\
H & D-glucopyranose compounds \\
J & 3-Pyridinol \\
K & 1,2-Benzenediol \\
L & Levoglocosan \\
\hline
\end{tabular}

Actually, PCA is a decomposition of original data matrix into two smaller matrices, scores and loadings. In Equation 1, each column of T matrix is a PC and the first PC represents the maximum variance and the second one maximum residual variance and so on till the total variance is explained. Previous investigations demonstrated that the first two PCs normally explain most of the total variance of the data [22].

The main goal of the PCA was to identify the main factors affecting the distribution of pyrolysis products. PCA was used to identify the pyrolysis process parameters affecting the yields of chemicals in bio-oil samples obtained by fast pyrolysis experiments and then GC-MS analyses. PCA was conducted for 24 experimental conditions/cases (missing 3 GC-MS analysis results) as in Table 1. Since the number of PCs must be equal or less than the smallest number of samples or variables, it was set as 10 . As a common rule to determine the main PCs is that the PCs with eigenvalues above one should be included in the analysis. There were three PCs with eigenvalues above one, but the first two PCs were used in the analyses and they explained $74 \%$ of the total variance.

HCA is a method to classify samples or variables into groups by measuring their similarities [23]. There are a number of linkage method such as average, centroid, complete, median, single, and ward. Similarly, there are a number of distance measuring 
method such as euclidean, manhattan, person, and squared euclidean and pearson. The Ward and Euclidean Methods, which are the most commonly used in cluster analysis [24], were used as the linkage and distance measures, respectively, in this study. Since the variables had large differences in scaling, standardization was performed before computing proximities, which can be performed automatically by the HCA procedure. Percentage values of GC-MS peak areas were set as variables, whereas 24 experimental runs were set as samples in PCA and HCA. Both PCA and HCA were carried out using statistical software "Minitab" 17.0 at $95 \%$ confidence level. The software produces score and loading plots, which are the maps of samples and variables, respectively, and bi-plot which is the combination of the two (score and loading plots) in PCA. A dendrogram is produced to visually see the correlations or similarity among elements or clusters in HCA.

\section{Results and discussion}

Descriptive statistics of variables used in this study is tabulated in Table 4. Since bio-oil samples of three experimental treatments (experiments 11,21, and 22) could not be analyzed by GC-MS, 24 samples/observations of each variable were used in the study. The vast majority of peak areas of chemicals were over 2 , where $2,2,6,2,2,12,3$, and 4 bio-oil samples out of 24 had peak areas lower than 2 for chemicals B, C, D, E, F, G, H, and $\mathrm{J}$, respectively (chemicals are defined in Table 3 ). The chemicals $\mathrm{L}, \mathrm{A}$, and $\mathrm{K}$ were in the highest amount with the mean peak areas of $15.54,7.41$, and $5.13 \%$, respectively, on the other hand, the remaining chemicals had the mean peak areas with the range 2.09 and $3.76 \%$. The maximum peak areas of the chemicals changed between 2.60 and $19.56 \%$ and SD changed between 0.36 and $3.24 \%$, indicating relatively homogeneous distribution of chemicals. The distributions of the most of the chemicals (8 out of 11) were left-skewed, where the values of skewness are negative.

Table 4: Descriptive statistics of variables (bio-oil compounds) used in the study $(n=24$ each).

\begin{tabular}{cccccc}
\hline Variables* & Min. & Mean & Max. & SD & Skewness \\
\hline A & 2.87 & 7.41 & 10.00 & 1.58 & -1.76 \\
B & 1.68 & 3.76 & 5.11 & 0.79 & -1.37 \\
C & 1.54 & 3.48 & 4.66 & 0.83 & -0.97 \\
D & 0.59 & 2.46 & 4.31 & 0.87 & -0.56 \\
E & 1.22 & 3.15 & 4.07 & 0.73 & -1.42 \\
F & 1.88 & 2.52 & 3.52 & 0.39 & 0.71 \\
G & 0.81 & 2.09 & 3.34 & 0.66 & 0.32 \\
H & 1.39 & 2.58 & 3.10 & 0.45 & -1.48 \\
J & 1.22 & 2.19 & 2.60 & 0.36 & -1.68 \\
K & 4.24 & 5.13 & 6.13 & 0.48 & 0.18 \\
L & 7.18 & 15.54 & 19.56 & 3.24 & -1.42 \\
\hline *: Variables are defined in Table 3. SD: Standard deviation. &
\end{tabular}

Eigen values and individual and cumulative variances of PCs are tabulated in Table 5.

Table 5: Variances of principal components.

\begin{tabular}{cccc}
\hline $\begin{array}{c}\text { Principal } \\
\text { Component }\end{array}$ & Eigenvalue & $\begin{array}{c}\text { Individual \% } \\
\text { Variance }\end{array}$ & $\begin{array}{c}\text { Cumulative } \\
\text { \% Variance }\end{array}$ \\
\hline PC1 & 6.7342 & 61 & 61 \\
PC2 & 1.4352 & 13 & 74 \\
PC3 & 1.1387 & 10 & 85 \\
PC4 & 0.6210 & 6 & 90 \\
PC5 & 0.4621 & 4 & 95 \\
PC6 & 0.3337 & 3 & 98 \\
PC7 & 0.1156 & 1 & 99 \\
PC8 & 0.0978 & 1 & 99 \\
PC9 & 0.0356 & 0 & 100 \\
PC10 & 0.0196 & 0 & 100 \\
\hline
\end{tabular}

Very large eigenvalue (6.7342) of PC1 compared to that of other PCs as shown in scree plot of chemicals (Figure 3) corresponded to explaining variance in Table 4. PC1 alone explained $61 \%$ of the total variance, but PC1 together with PC2 explained $74 \%$ of the total variance. The first three PCs had significant contribution to explain variance, where eigenvalues were over one, but the change in eigenvalues was very small after the first three PCs (Figure 3 and Table 5).

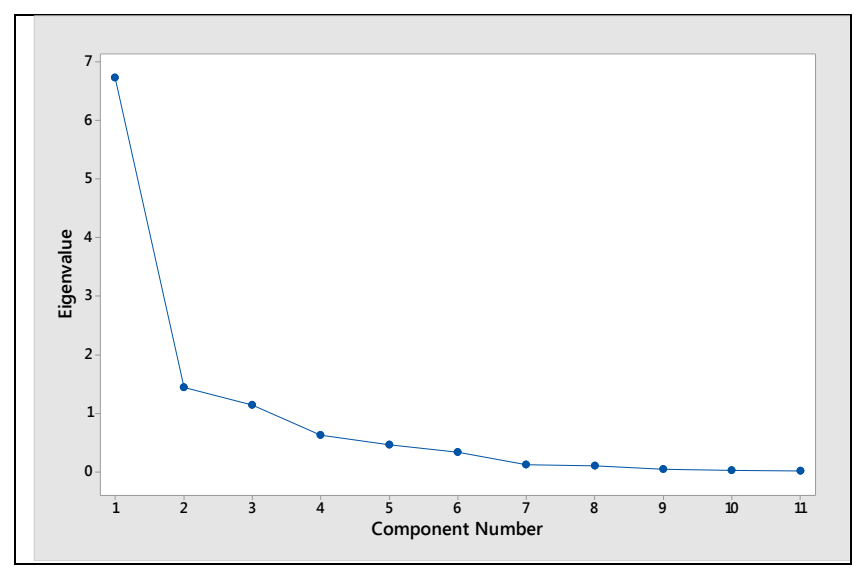

Figure 3: Scree plot of PCA of chemicals in bio-oil.

Eigenvectors in PCs, expressing correlations among variables (chemicals) and PCs (PC1 through PC10), are presented in Table 6. The higher the eigenvector magnitude, the more correlation between the original variable and the PC. The correlations may be either directly (positive sign) or inversely (negative sign) proportional. There were significant positive correlations between variable F and PC2, variable D and PC4, variable $\mathrm{E}$ and $\mathrm{PC} 8$, variable $\mathrm{C}$ and $\mathrm{PC}$, and variable $\mathrm{H}$ and $\mathrm{PC} 10$ but negative correlation between variable $\mathrm{K}$ and PC3. An improvement in the value of $\mathrm{PC} 2$ resulted in an increment in the value of variable $F$ and a decrement in the value of variable $D$, whereas a reduction in this principle component implied an improvement in the variable $D$ value and a decrease in the value of variable $\mathrm{F}$ (Table 6).

Table 6. Eigenanalysis of the correlation matrix.

\begin{tabular}{cccccc}
\hline Variable & PC1 & PC2 & PC3 & PC4 & PC5 \\
\hline A & 0.359 & 0.198 & 0.059 & 0.067 & 0.136 \\
B & 0.357 & 0.287 & 0.050 & 0.061 & 0.053 \\
C & 0.356 & 0.063 & 0.168 & 0.109 & -0.248 \\
D & 0.225 & -0.446 & 0.085 & 0.645 & -0.368 \\
E & 0.358 & -0.038 & 0.124 & 0.055 & -0.160 \\
F & 0.181 & 0.652 & -0.071 & -0.114 & -0.340 \\
G & 0.197 & -0.375 & -0.436 & -0.574 & -0.489 \\
H & 0.367 & -0.003 & -0.090 & -0.089 & 0.152 \\
J & 0.363 & -0.109 & -0.041 & -0.123 & 0.241 \\
K & -0.008 & 0.158 & -0.856 & 0.428 & 0.107 \\
L & 0.316 & -0.267 & -0.072 & -0.111 & 0.556 \\
\hline Variable & PC6 & PC7 & PC8 & PC9 & PC10 \\
\hline A & -0.359 & -0.012 & -0.308 & -0.459 & 0.177 \\
B & -0.125 & 0.045 & -0.090 & -0.253 & 0.327 \\
C & -0.338 & -0.238 & -0.363 & 0.629 & -0.259 \\
D & 0.360 & -0.042 & -0.091 & -0.229 & 0.019 \\
E & -0.269 & 0.587 & 0.619 & 0.099 & -0.089 \\
F & 0.543 & 0.112 & -0.046 & -0.066 & -0.286 \\
G & -0.086 & 0.036 & -0.156 & -0.143 & 0.080 \\
H & 0.349 & -0.241 & 0.230 & 0.393 & 0.628 \\
J & 0.012 & -0.571 & 0.394 & -0.252 & -0.482 \\
K & -0.165 & 0.023 & 0.055 & 0.109 & -0.068 \\
L & 0.297 & 0.443 & -0.370 & 0.109 & -0.258 \\
\hline & & & & &
\end{tabular}


The results of PCA are presented in Figures 4(a-c). The samples were clustered into four different groups: samples $3,16,17,18$, 20,26 , and 27 were in group 1; samples $1,2,4,7,9,12,13$, and 14 were in group 2 ; samples $5,6,8,19$, and 23 were in group 3 ; and samples 15, 24 and 25 were in group 4. Most of the samples in group 1 with intermediate and high carrier gas flows $(1000$ and $1500 \mathrm{~mL} / \mathrm{min}$ ) and intermediate catalyst amounts (7.5 g) had similar effects on chemicals productions. In group 2, most of the samples with low carrier gas flows $(500 \mathrm{~mL} / \mathrm{min})$ and half of the samples with small catalyst particle sizes (0.50-1.00 $\mathrm{mm}$ ) produced similar amounts of chemicals. Most of the samples in group 3 with intermediate catalyst particle sizes (1.00-1.50 mm), carrier gas flows and catalyst amounts had similar effects on chemicals productions. In group 4, samples 15 and 24 had intermediate catalyst amounts and high catalyst particle sizes (1.50-2.00 mm). Sample 10 alone seems to be an outlier, may be because of experimental errors or some other unknown reasons. The first three groups were similar, therefore, in the score plot of PCs (Figure 4a) these groups were close to each other but distant from group 4. This implies that there may not be a significant change in the bio-oil quality if these process parameters are used. There were two main groups of chemicals separated by PC1 which explains $61 \%$ of the total variance: one on the left side of the origin, and the other on the right side of the origin.

The plot of loading factors is shown in Figure 4(b). This plot can be used to visualize the relationship between PC1 and PC2 and the pyrolytic chemicals formed. The capital letters inside the graph correspond to chemicals (Table 3 ). The chemicals were found to group in two major clusters: chemicals A, B, C, E, H and $J$ and chemicals $D, G$ and $L$. There was no clear grouping of chemicals $\mathrm{F}$ and $\mathrm{K}$.

Two PC plots were combined into one bi-plot of scores (Figure 4(a) and loadings (Figure 4(b) as shown in Figure 4(c). Figure 3(c) shows an identifiable cluster between samples (pyrolysis process parameters) and variables (chemicals), where samples $(1,2,4,8,9,12,13,14$ and 16) and all variables were clustered on the right of Figure 3(c). This showed that there were close relationships between samples in group 2 and all variables, indicating that the yields of chemicals were affected by these pyrolysis process parameters represented by samples in group 2. Even though there is no substantial difference between PCA and HCA, HCA can be used as an alternative method to confirm the results. HCA results are represented as a dendrogram and shown in Figure 5 . The classification of samples and variables was made using the Ward's method. The distance axis (y-axis) of dendrogram represents the degree of association between groups of samples or variables, i.e. the lower the value on the axis, the more significant the association. Samples or pyrolysis process parameters or experimental treatments were clustered in two main groups (Figure 5(a). Samples 14, 21, and 22 were clustered as in one group with similar patterns, whereas the remaining samples were clustered as another group. In terms of subclustering, samples 7 and 10 showed some difference from the group of other samples. On the other hand, variables were clustered in two main groups (Figure 5(b). Variables $\mathrm{F}$ and $\mathrm{K}$ were clustered as in one group with similar patterns, whereas the remaining variables were clustered as another group. In terms of subclustering, variables $D$ and $G$ showed some difference from the group of other variables.

[17] presented the effects different factors such as storage days, biomass particle size, wrap type, and weight of the bale on the chemical composition of switchgrass and the generation of biofuels by PCA. PC1 and PC2 explained approximately $80 \%$ of the total variance. Pattiya et al. [18] investigated the effects of various catalysts on the distribution of pyrolysis products $(102$ different chemicals in bio-oil) of rhizome of cassava plants. The results showed that catalysts were effective on the distribution pyrolysis products such as oxygenated compounds, aromatic hydrocarbons, phenols, carbonyl compounds, acetic acid, and formic acids. Catalysts formed distinct clusters in terms of effects on chemical distribution.

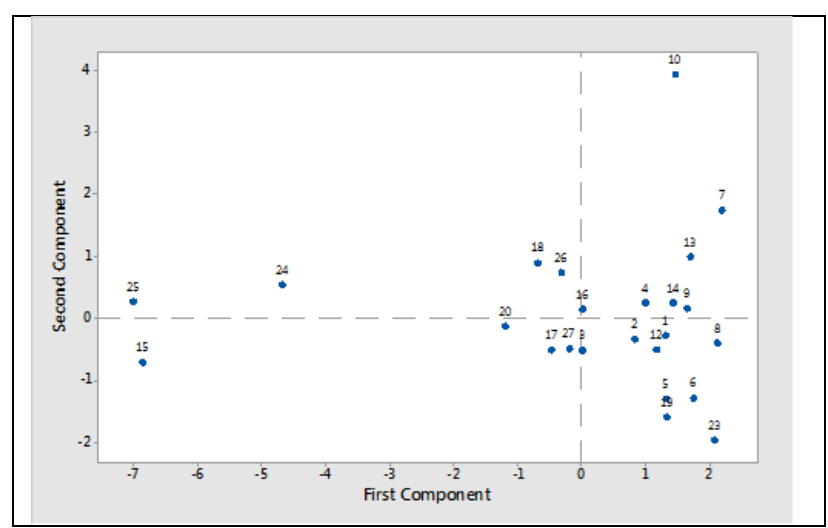

(a)

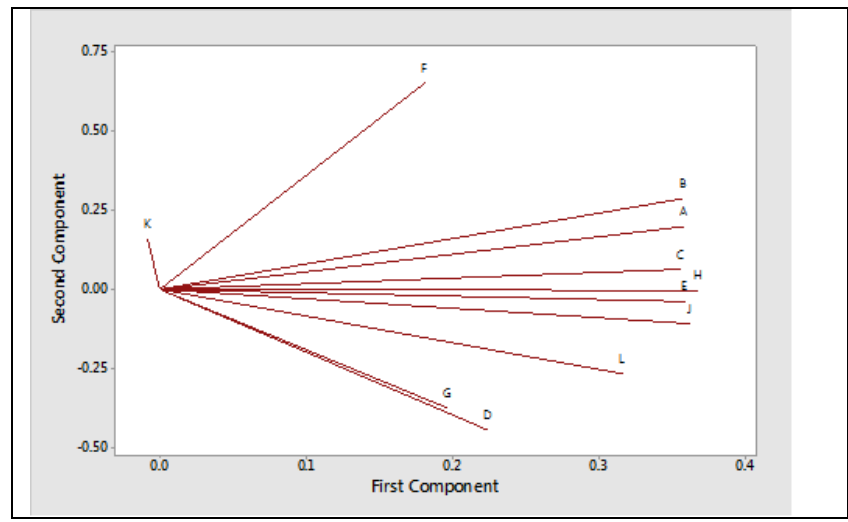

(b)

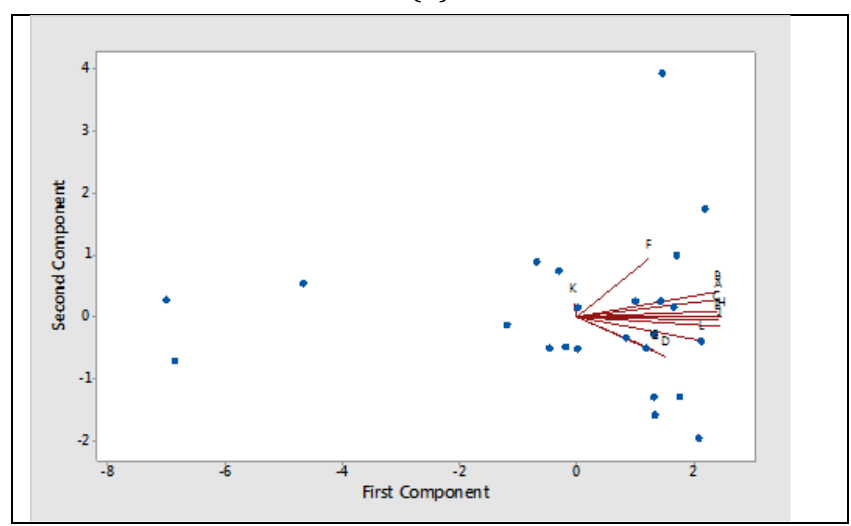

(c)

Figure 4(a): Score plot. (b): Loading plot and (c): Bi-plot of PC1 and PC2 for chemicals in bio-oil pyrolyzed at different process conditions.

Liaw et al. [20] conducted a study to investigate the effects of pyrolysis temperature on the distribution of pyrolysis products derived from different biomass materials. The products were 
clustered into five groups based on biomass materials. The first two PCs represented $72.52 \%$ of the total variance. Biomass materials formed four different clusters in terms of effects on chemical distribution. The results of this study were similar to the three studies in the literature in respect to the number of clusters or groups. And also, the first two PCs of this study explained the significant amount of the total variance (74\%) as in the literature, indicating a high performance clustering through PCA.
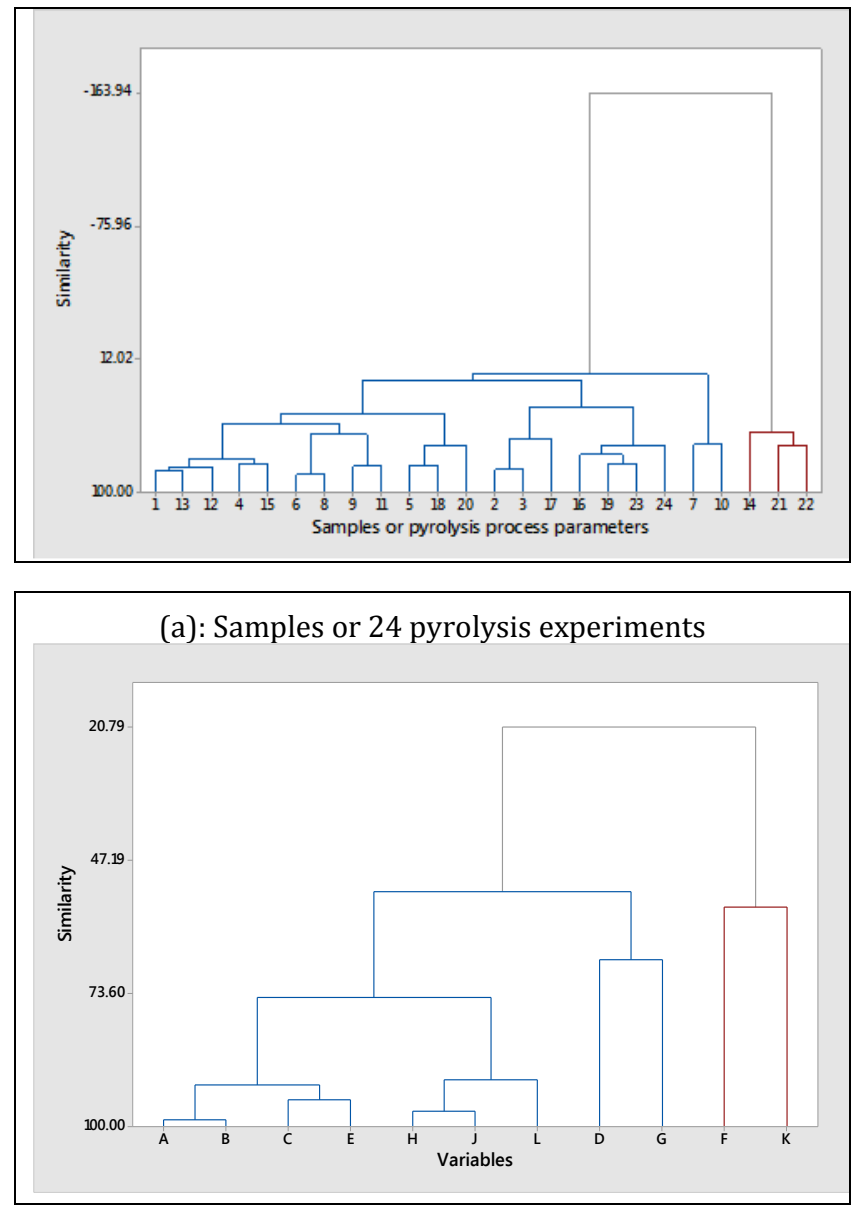

(b): Variables or chemical compounds.

Figure 5: Dendrogram of HCA performed using Euclidian distance and Ward's linkage for.

MSW (paper waste, yard waste, construction and demolition waste) were used in a bench scale fast micropyrolysis system to investigate the potential yields of bio-oil. Construction and demolition materials had the highest bio-oil yield, but paper had the lowest yield. Chemical compounds derived from different MSW were also different [25]. A total of 26 kinds of MSW components were classified by cluster analysis technique based on the proximate and ultimate analyses, heating values, and thermogravimetric (TG) data. The classification groups were vegetables, starch food, orange peel, wood waste, printing paper, cellulose, PVC, PET, PE/PP, PS, and rubber. Since MSW components have different classification groups based on their characteristics, chemicals in bio-oils are also expected to be different [26]. The effects of different catalysts on the yield and composition of bio-oil produced from MSW by pyrolysis were investigated and the results showed that different catalyst configuration produced bio-oils with various quantity and quality [27]. Ouadi et al. [28] investigated the conversion of
MSW into fuels and chemicals by pyrolysis. The analysis of biooil samples revealed bio-oils with different physical and chemical properties. All the results of these studies from the literature with different process condition illustrate that different MSW components produce bio-oils with different yields and chemicals as in this study, indicating that further studies need to be conducted for better understanding of the interactions of input (MSW), process conditions, and output (bio-oil yield and composition).

\section{Conclusion}

In this study, chemicals in bio-oil produced from municipal solid wastes were classified based on the treatments/pyrolysis process parameters by using multivariate analysis techniques (PCA and HCA). PCA compressed different characters into 3 major PCs and the first two PCs explained $74 \%$ of the total variance. The samples and variables were clustered into 4 and 2 different groups, respectively, and close relationships between samples in group 2 and whole variables were observed in PCA. On the other hand, in HCA, samples and variables were clustered in 2 main groups and some subgroups.

PCA and HCA illustrate that the pyrolysis products can be divided into groups and their behaviors are strongly affected by the process parameters. Another way to say is that it is found that the yields of chemical compounds have a response to the process parameters. Both techniques are proved to be a powerful tool to discriminate the formation of the pyrolytic chemicals as a function of pyrolysis process parameters. Further studies may be conducted with different configurations of the process parameters and products since both techniques are promising in multivariable data analysis.

\section{Acknowledgment}

This work was financially supported by Scientific Research Projects (BAP) Division of Akdeniz University with the project number of FYL-2016-1211.

\section{References}

[1] Serrano-Ruiz JC, Dumesic JA. "Catalytic production of liquid hydrocarbon transportation fuels". (In: Catalysis for Alternative Energy Generation, Edited by Guczi, L. and Erdohelyi, A.), Springer Science and Business Media, New York, USA, 2012.

[2] Siedlecki M, de Jong W, Verkooijen AHM. "Fluidized bed gasification as a mature and reliable technology for the production of bio-syngas and applied in the production of liquid transportation fuels-A review". Energies, 4, 389-434, 2011.

[3] Bridgwater AV. "Review of fast pyrolysis of biomass and product upgrading”. Biomass \& Bioenergy, 38, 68-94, 2012.

[4] Mohan D, Pittman CU, Steele PH. "Pyrolysis of wood/biomass for bio-oil: A critical review". Energy \& Fuels, 20, 848-889, 2006.

[5] Venderbosch RH, Prins W. "Fast pyrolysis technology development". Biofuels, Bioproducts \& Biorefining, 4, 178-208, 2010.

[6] Bulushev DA, Ross JRH. "Catalysis for conversion of biomass to fuels via pyrolysis and gasification: A review". Catalysis Today, 171, 1-13, 2011.

[7] Li J, Li X, Zhou G, Wang W, Wang C, Komarneni S, Wang Y. "Catalytic fast pyrolysis of biomass with mesoporous ZSM5 zeolites prepared by desilication with $\mathrm{NaOH}$ solutions". Applied Catalysis A: General, 470, 115-122, 2014. 
[8] Zhang Y, Xiao R, Gu X, Zhang H, Shen D, He G. “Catalytic pyrolysis of biomass with $\mathrm{Fe} / \mathrm{La} / \mathrm{SBA}-15$ catalyst using TGA-FTIR analysis". Bioresources, 9(3), 5234-5245, 2014.

[9] Freel BA, Graham RG, Huffman DR. "Commercial aspects of rapid thermal processing (RTM)". In: Bridgwater, A.V., Hogan, E. Editors: Bio-oil Production and Utilization. Newbury, UK, CPL Press, p. 86-95, 1996.

[10] Gust S. "Combustion experiences of flash pyrolysis fuel in intermediate size boilers". In: Bridgwater, A.V., Boocock, D.G.B., Editors. Developments in thermochemical biomass conversion. London, Blackie Academic \& Professional, p. 481-488, 1997.

[11] Chiaramonti D, Bonini A, Fratini E, Tondi G, Gartner K, Bridgwater AV. "Development of emulsions from biomass pyrolysis liquid and diesel and their use in engines-Part 2: tests in diesel engines". Biomass and Bioenergy, 25, 101-111, 2003.

[12] Crayford AP, Bowen PJ, Kay PJ, Laget H. "Comparison of gas-oil and bio-oil spray performance for use in a gas turbine". Proceedings of the ASME Turbo Expo, 659-667, 2010.

[13] Czernik S, Bridgwater AV. "Applications of biomass fast pyrolysis oil”. Energy \& Fuels, 18, 590-598, 2004.

[14] Balat M. "An overview of the properties and applications of biomass pyrolysis oils". Energy Sources Part A-Recovery, Utilization and Environmental Effects, 33(7), 674-689, 2011.

[15] Esbensen KH, Guyot D, Westad F, Houmøller LP. In: K.H. Esbensen/with contributions from Dominique Guyot, Frank Westad, Lars P. Houmøller Editors: Multivariate Data Analysis: In practice: An İntroduction to Multivariate Data Analysis and Experimental Design. $5^{\text {th }}$ ed. Camo Process AS, 2002.

[16] Loska K, Wiechuya D. "Application of principle component analysis for the estimation of source of heavy metal contamination in surface sediments from the Rybnik Reservoir". Chemometry, 51, 723-733, 2003.

[17] Aboytes-Ojeda M, Castillo-Villar KK, Yu TE, Boyer CN, English BC, Larson JA, Kline LM, Labbé N. "A principal component analysis in switchgrass chemical composition". Energies, 913, 1-12, 2016.

[18] Pattiya A, Titiloye J0, Bridgwater AV. "Evaluation of catalytic pyrolysis of cassava rhizome by principal component analysis". Fuel, 89, 244-253, 2010.
[19] Wang L, Wang C, Pan Z, Sun Y, Zhu X. "Application of pyrolysis-gas chromatography and hierarchical cluster analysis to the discrimination of the Chinese traditional medicine Dendrobium candidum Wall. ex Lindl". Journal of Analytical and Applied Pyrolsis, 90, 13-17, 2011.

[20] Liaw SS, Perez VH, Zhou S, Rodriguez-Justo O, GarciaPerez M. "Py-GC/MS studies and principal component analysis to evaluate the impact of feedstock and temperature on the distribution of products during fast pyrolysis". Journal of Analytical and Applied Pyrolsis, 109, 140-151, 2014.

[21] Ražić SS, Đogo SM, Slavković LJ. "Multivariate characterization of herbal drugs and rhizosphere soil samples according to their metallic content". Microchemical Journal, 84, 93-101, 2006.

[22] Galvao LS, Vitorello I. "Quantitative approach in the spectral reflectance-lithostratigraphy of the wind-river and Southern Bighorn Basins, Wyoming". International Journal of Remote Sensing, 16(9), 1617-1631, 1995.

[23] Dragovic S, Onjia A. "Classification of soil samples according to their geographic origin using gamma-ray spectrometry and principal component analysis". Journal of Environmental Radioactivity, 89, 150-158, 2006.

[24] Hair JR, Anderson RE, Tatham RL, Black WC. Multivariate Data Analysis with Readings. $4^{\text {th }}$ ed. Englewood Cliffs, New Jersey, USA, Prentice Hall, 1995.

[25] Klemetsrud B, Ukaew S, Thompson VS, Thompson DN, Klinger J, Li L, Eatherton D, Puengprasert P, Shonnard D. "Characterization of products from fast micropyrolysis of municipal solid waste biomass". ACS Sustainable Chemistry and Engineering, 4, 5415-5423, 2016.

[26] Zhou H, Long Y, Meng A, Li Q, Zhang Y. “Classification of municipal solid waste components for thermal conversion in waste-to-energy research". Fuel, 145, 151-157, 2015.

[27] Li J, Xia H, Wu Q, Hu Z, Hao Z, Zhu Z. "Hydrocracking of the crude oil from thermal pyrolysis of municipalwastes over bi-functional Mo-Ni catalyst". Catalysis Today, 271, 172$178,2016$.

[28] Ouadi M, Jaeger N, Greenhalf C, Santos J, Conti R, Hornung A. "Thermo-catalytic reforming of municipal solid waste". Waste Management, 68, 198-206, 2017. 